\title{
Recent Updates on the Melanin-Concentrating Hormone (MCH) and Its Receptor System: Lessons from MCH1R Antagonists
}

\author{
Shinjae Chung • Gregory S. Parks • Cheol Lee • \\ Olivier Civelli
}

Received: 27 April 2010 / Accepted: 11 June 2010 / Published online: 26 June 2010

(C) The Author(s) 2010. This article is published with open access at Springerlink.com

\begin{abstract}
Melanin-concentrating hormone (MCH) is a 19amino-acid cyclic peptide which was originally found to lighten skin color in fish that is highly conserved among many species. $\mathrm{MCH}$ interacts with two G-protein-coupled receptors, MCH1R and MCH2R, but only MCH1R is expressed in rodents. $\mathrm{MCH}$ is mainly synthesized in the lateral hypothalamus and zona incerta, while MCH1R is widely expressed throughout the brain. Thus, $\mathrm{MCH}$ signaling is implicated in the regulation of many physiological functions. The identification of MCH1R has led to the development of small-molecule MCH1R antagonists that can block $\mathrm{MCH}$ signaling. MCH1R antagonists are useful not only for their potential therapeutic value, but also for understanding the physiological functions of the endogenous $\mathrm{MCH}$ system. Here, we review the physiological functions of the $\mathrm{MCH}$ system which have been investigated using MCH1R antagonists such as food intake, anxiety, depression, reward, and sleep. This will help us understand the physiological functions of the $\mathrm{MCH}$ system
\end{abstract}

S. Chung $\cdot$ G. S. Parks $\cdot$ C. Lee $\cdot$ O. Civelli $(\bowtie)$

Department of Pharmacology, University of California,

369 Med Surge II,

Irvine, CA 92612, USA

e-mail: ocivelli@uci.edu

G. S. Parks • O. Civelli

Department of Developmental and Cell Biology,

University of California Irvine,

Irvine, CA, USA

C. Lee

Department of Anesthesiology and Pain Medicine,

College of Medicine, Wonkwang University,

Chonju, Korea

O. Civelli

Department of Pharmaceutical Sciences,

University of California Irvine,

Irvine, CA, USA and suggest some of the potential applications of MCH1R antagonists in human disorders.

Keywords Melanin-concentrating hormone (MCH) . G-protein-coupled receptors (GPCRs) - Antagonists . Energy homeostasis

\section{Introduction}

Melanin-concentrating hormone ( $\mathrm{MCH})$ was initially discovered in 1983 to be a 17-amino-acid cyclic peptide that induces paling of the skin in fish (Kawauchi et al. 1983). In 1996, $\mathrm{MCH}$ was discovered to be overexpressed in rodents upon fasting and in ob/ob mice (Qu et al. 1996). Central MCH injection increases food intake, suggesting that $\mathrm{MCH}$ is an orexigenic peptide. Mice lacking precursor $\mathrm{MCH}$ (ppMCH) have been shown to be hypophagic and lean (Shimada et al. 1998). These lines of evidence suggest that the MCH system modulates energy homeostasis. However, its site of action was not known until 1999 when we and other groups discovered a receptor for MCH (Bachner et al. 1999; Chambers et al. 1999; Lembo et al. 1999; Saito et al. 1999; Shimomura et al. 1999). MCH1 receptor is a Gprotein-coupled receptor that couples to $\mathrm{Gi}$ and $\mathrm{Gq}$ proteins (Hawes et al. 2000). MCH is exclusively expressed in the hypothalamus and zona incerta whereas MCH1R is widely expressed in central and peripheral tissues. MCH1R distribution is particularly widespread throughout the brain, being particularly concentrated in areas such as the cortex, hippocampus, amygdala, and nucleus accumbens shell (Saito et al. 2001), suggesting that the MCH system may be involved in a wide range of physiological functions in the central nervous system. MCH1R is also expressed in many peripheral tissues such as pituitary, intestine, lymphocytes, and adipose tissue (Hill et al. 2001), suggesting peripheral 
sites of $\mathrm{MCH}$ action and involvement in peripheral physiological functions. In 2001, another receptor for $\mathrm{MCH}$, $\mathrm{MCH} 2 \mathrm{R}$, which exists in humans but not in rodents, was discovered (Hill et al. 2001; Sailer et al. 2001).

Studies using ppMCH knockout mice or MCH1R knockout mice suggested that the $\mathrm{MCH}$ system might be involved in regulating energy homeostasis (Marsh et al. 2002; Shimada et al. 1998). Genetic knockout mice are useful animal models to understand the physiological functions of the MCH system. However, significant developmental compensation can occur as a result of germ line gene disruption leading to discordant results between genetic and pharmacological studies. Examples of discrepancies between results obtained through genetic versus pharmacological studies have been seen with $\mathrm{MCH}$ and other signaling systems. MCH1R knockout mice are hyperphagic (Marsh et al. 2002) whereas central MCH injection increases food intake ( $\mathrm{Qu}$ et al. 1996). Another example of this phenomenon was seen when neuropeptide $Y$ (NPY)5R knockout mice exhibit a mildly obese phenotype (Marsh et al. 1998) while NPY5R antagonists cause mild weight loss (Erondu et al. 2006; Ishihara et al. 2006). Therefore, the use of pharmacological antagonists to understand the biological functions of a system is crucial to avoid the confounding effects of developmental compensations which are often present in knockout and transgenic animals.

Here, we review what has been learned about the physiological functions of the MCH system by blocking endogenous $\mathrm{MCH}$ signaling with MCH1R antagonists. In particular, we will focus on the role of $\mathrm{MCH}$ in food intake, anxiety, depression, reward, and sleep.

\section{MCH1R Antagonists and Energy Homeostasis}

Central $\mathrm{MCH}$ injection increases food intake $(\mathrm{Qu}$ et al. 1996) while mice lacking ppMCH are hypophagic and lean (Shimada et al. 1998), and MCH1R KO mice are hyperphagic, hyperactive, and lean (Marsh et al. 2002). This strongly suggests that $\mathrm{MCH}$ signaling is involved in energy balance and food intake.

In 2002, two papers were published indicating that smallmolecule MCH1R antagonists, SNAP-7941 and T-226296, may be useful in the treatment of obesity (Borowsky et al. 2002; Takekawa et al. 2002). Systemic injections of both MCH1R antagonists decreased MCH-induced food intake, and chronic SNAP-7941 administration decreased body weight in rats with diet-induced obesity (DIO).

Numerous small-molecule MCH1R antagonists have since been developed and have consistently been effective in animal models of DIO (Borowsky et al. 2002; Eric Hu et al. 2008; Gehlert et al. 2009; Ito et al. 2010; Kowalski et al. 2006; Luthin 2007; Mashiko et al. 2005), reviewed in (Luthin 2007; McBriar 2006). Chronic administration of MCH1R antagonists successfully decreased food intake and body weight gain induced by high calorific food consumption. The central MCH system seems to play an important role in regulating energy balance and metabolism since Mashiko et al. (2005) showed that chronic central infusions of a peptide MCH1R antagonist into DIO mice only slightly decreased food intake but significantly reduced body weight. Another study reported that only MCH1R antagonists which can cross the blood brain barrier (BBB) are able to decrease food intake and body weight, while those that do not are ineffective (Eric Hu et al. 2008). However, the BBBcrossing antagonist used in this study also induced a modest conditioned taste aversion (Eric $\mathrm{Hu}$ et al. 2008), which complicates interpretation of these results. Additional studies found that central MCH1R antagonist injection reduced MCH-induced food intake but failed to decrease spontaneous food intake when it was injected alone (Audinot et al. 2009; Morens et al. 2005).

Although there is strong evidence that the central $\mathrm{MCH}$ system plays an important role in modulating food intake and body weight gain, many studies suggest that peripheral MCH1R signaling may also be involved in modulating these processes since MCH1Rs are expressed in a variety of peripheral tissues. It has been shown that the $\mathrm{MCH}$ system modulates leptin secretion and insulin release (Bradley et al. 2000; Tadayyon et al. 2000), suggesting that systemic injections of MCH1R antagonist may modulate food intake and body weight through both peripheral and central mechanisms. Thus, peripheral MCH1R antagonist administration will affect not only the brain, but also peripheral tissues such as brown adipose tissues, liver, pancreas, small intestines, and white adipose tissues.

Some studies suggest that MCH1R antagonist-induced weight loss may not be exclusively due to inhibition of feeding but may also involve an increase in metabolism (Huang et al. 2005; Ito et al. 2010). It has been reported that administration of a MCH1R antagonist only moderately suppressed feeding but led to a significant reduction in body weight (Ito et al. 2010). Pair feeding resulted in a significant weight loss, suggesting that MCH1R antagonism can modulate energy expenditure which leads to weight loss. Therefore, antiobesity effects of the MCH1R antagonists may be caused not only by a suppression of feeding, but also by an increase in energy expenditure.

These studies strongly indicate that pharmacological blockade of $\mathrm{MCH}$ signaling leads to a reduction in body weight and demonstrate that the $\mathrm{MCH}$ system is a promising target for the treatment of obesity.

\section{MCH1R Antagonists and Anxiety}

MCH1 receptors are widely distributed throughout the limbic brain regions that regulate stress and anxiety. Central $\mathrm{MCH}$ injection has been shown to be anxiogenic (Smith et al. 2006) 
or anxiolytic (Monzon and De Barioglio 1999; Monzon et al. 2001), and MCH1R KO mice exhibit less anxiety-like behaviors than wild-type mice (Roy et al. 2007; Smith et al. 2006), suggesting that the MCH system plays a critical role in anxiety-like behaviors. In order to avoid potentially confounding effects inherent in the injection and knockout mouse studies, several groups have used MCH1R antagonists to investigate the role of endogenous $\mathrm{MCH}$ signaling in anxiety (summarized in Table 1).

In 2002, the MCH1R antagonist SNAP-7941 was shown to exhibit anxiolytic properties in the separation-induced vocalization test in guinea pig pups and to increase the interaction time of paired unfamiliar rats in a social interaction test (Borowsky et al. 2002). Following this initial discovery, another MCH1R antagonist, SNAP-94847, was found to display anxiolytic properties in the light-dark transition test following both acute and chronic administration (David et al. 2007). Additionally, chronic administration of SNAP-94847 was found to be anxiolytic in the rat novelty-suppressed feeding test (David et al. 2007).

Two other MCH1R antagonists, ATC0065 and ATC0175, significantly reverse swim stress-induced anxiety in the elevated plus maze test in rats and stress-induced hyperthermia in mice (Chaki et al. 2005). ATC0175 also increased social interaction between unfamiliar rats and reduced separation-induced vocalizations in guinea pig pups. Interestingly, both of these compounds were found to be ineffective in the marble burying task.

Another MCH1R antagonist, GW803430 (also referred to as GW3430), exhibits anxiolytic activity in a diverse array of behavioral models including the marble burying task, elevated plus maze, and stress-induced hyperthermia without affecting motor activity in mice (Gehlert et al. 2009; Smith et al. 2006). GW803430, along with SNAP7941 , has also been shown to have anxiolytic properties in a Vogel conflict test and ultrasonic vocalization test (Millan et al. 2008). Stressful stimuli are known to elevate plasma adrenocorticotropic hormone (ACTH) and corticosterone levels by activating the hypothalamic-pituitary-adrenal (HPA) axis (Herman et al. 1996). MCH administration increases ACTH and corticosterone levels, an effect that is reversed by pretreatment with GW803430 (Smith et al. 2006). This suggests that the anxiolytic activity of MCH1R antagonists may involve regulation of the HPA axis.

These studies consistently show that both acute and chronic MCH antagonisms have anxiolytic effects and strongly support a role for the $\mathrm{MCH}$ system in the modulation of stress and anxiety.

\section{MCH1R Antagonists and Depression}

Due to the dense expression of MCH1R in areas of the brain involved in stress, reward, and emotional regulation
(Saito et al. 2001), it was surmised that MCH signaling may regulate depression-like behaviors. Pharmacological support for this hypothesis was found when the MCH1R antagonist SNAP-7941 was discovered to reduce immobility time in the rat forced-swim test with similar efficacy as fluoxetine (Borowsky et al. 2002). Following this initial discovery, additional MCH1R antagonists, ATC0065 (Chaki et al. 2005), ATC0175 (Chaki et al. 2005), and GW803430 (Gehlert et al. 2009), were found efficacious in standard acute rodent depression models (McBriar 2006). In addition to high affinity for MCH1R, ATC0175 showed a moderate to high affinity for both $5-\mathrm{HT}_{2 \mathrm{~B}}$ and $5-\mathrm{HT}_{1 \mathrm{~A}}$ receptors, and ATC0065 showed a moderate affinity for 5$\mathrm{HT}_{1 \mathrm{~A}}$ receptors (Chaki et al. 2005). This nonspecific activity of ATC0065 and ATC0175 on other receptors could make it difficult to interpret the specificity of MCH1R involvement in the antidepressant effects of ATC0065 and ATC0175. Additionally, the MCH1R antagonist SNAP-94847 has recently been reported to be effective in reversing decreased sucrose intake in the chronic mild stress anhedonia model (Smith et al. 2009) and to decrease latency to novelty-suppressed feeding (David et al. 2007) although it was not effective in the forced-swim test. This indicates that MCH1R antagonists are effective in both chronic and acute models of depression.

The mechanism through which MCH1R antagonists exert antidepressant activity has thus far not been elucidated, but current studies suggest that it likely occurs through a mechanism distinct from existing antidepressants. MCH1R antagonists enhance time spent swimming without altering climbing behavior in the forced-swim test (Chaki et al. 2005), an effect typically seen with antidepressant compounds possessing primarily serotonergic activity (Detke et al. 1995). Chronic treatment with either selective serotonin reuptake inhibitors (SSRIs) or MCH1R antagonists induce hippocampal neurogenesis (David et al. 2007; Santarelli et al. 2003); however, neurogenesis is not required for chronic MCH1R antagonist effects (David et al. 2007), indicating a mechanism of action differing from SSRIs. Interestingly, it has also been shown that MCH1R antagonists may enhance adaptation to stressful stimuli (Smith et al. 2006) at least partially by modulating HPA axis response. Additionally, the MCH1R antagonist SNAP-94847 has a more rapid onset of action in the novelty-suppressed feeding task than a traditional antidepressant (David et al. 2007), highlighting a potential advantage of MCH1R as a target for the treatment of depression.

Despite a limited understanding of the role of endogenous $\mathrm{MCH}$ signaling in the regulation of emotion and the absence of detailed mechanistic studies into the nature of the antidepressant effects observed with MCH1R antagonism, 


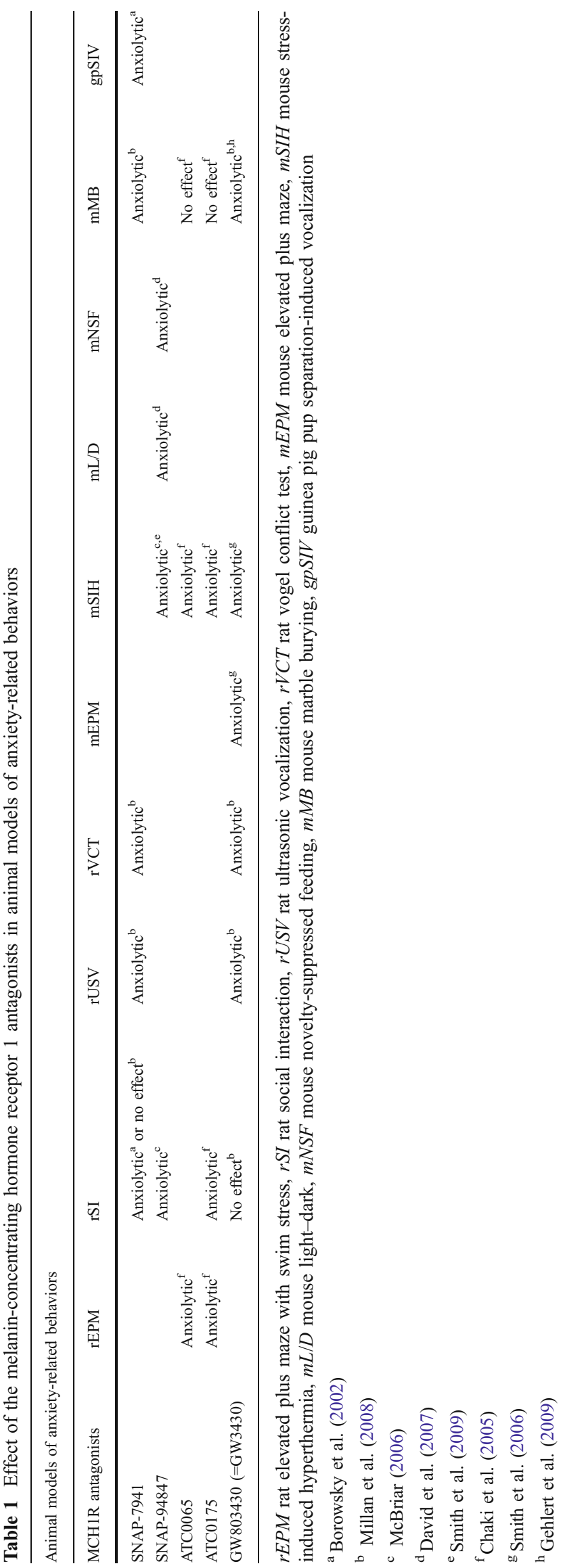

the $\mathrm{MCH} 1$ receptor appears to be a promising new target for the treatment of depression.

MCH1R Antagonists and Reward

MCH1Rs are highly expressed throughout the mesolimbic dopamine system (Saito et al. 2001), particularly in the nucleus accumbens shell (Chung et al. 2009), a region important in the regulation of rewarding behaviors. To study the role of the $\mathrm{MCH}$ system in cocaine reward behavior, the MCH1R antagonist TPI 1361-17 (Nagasaki et al. 2009) was acutely injected into rats undergoing cocaine self-administration (Chung et al. 2009). Acute blockade of the $\mathrm{MCH}$ system decreased cocaine selfadministration and cue- and cocaine-induced reinstatements. The role of the $\mathrm{MCH}$ system in food reward has also been studied. Systemic injections of a MCH1R antagonist, SNAP 94847, decreased high-fat foodreinforced operant responding and $\mathrm{MCH}$-induced reinstatement of food-seeking behaviors in rats (Nair et al. 2009), suggesting that the MCH system is also involved in food reward.

\section{MCH1R Antagonists and Sleep}

It has recently been shown that $\mathrm{MCH}$-producing neurons are primarily active during paradoxical (rapid eye movement (REM)) sleep and inactive during slow wave and waking states (Hassani et al. 2009; Verret et al. 2003), suggesting that $\mathrm{MCH}$ may regulate some aspects of REM sleep. ICV injection of MCH significantly increases time spent in paradoxical sleep (Verret et al. 2003), and mice lacking the $\mathrm{MCH}$ peptide (Willie et al. 2008) or receptor (Adamantidis et al. 2008) display altered sleep patterns. Several other studies have found that microinjection of $\mathrm{MCH}$ into brain nuclei with known involvement in sleep has modest effects on slow wave sleep but significantly increases paradoxical sleep time (Lagos et al. 2009). Somewhat surprisingly, relatively few studies have focused on how $\mathrm{MCH}$ antagonism affects sleep. One study found that two MCH1R antagonists, compound A and compound $B$, reduced both deep sleep and REM sleep while increasing time spent awake (Ahnaou et al. 2008), though it should be noted that both compounds possess affinity for the muscarinic $\mathrm{M}_{1}$ receptor and compound $\mathrm{A}$ for the dopamine transporter, targets known to affect sleep parameters. Conversely, another group reported that high occupancy of MCH1R with another MCH1R antagonist also named compound A does not affect sleep (Able et al. 2009). While $\mathrm{MCH}$ injection, neuroanatomical, and knockout mouse studies all point towards the involvement of $\mathrm{MCH}$ signaling in the regulation of REM sleep, reports of the effects of MCH1R antagonism on sleep are limited and 
conflicting. Further antagonist studies are needed to elucidate how endogenous $\mathrm{MCH}$ signaling is involved in sleep.

\section{Conclusion}

Here, we have reviewed studies into physiological functions regulated by the $\mathrm{MCH}$ system using $\mathrm{MCH} 1 \mathrm{R}$ antagonists. Most MCH1R antagonists have been shown to be effective in reducing body weight in rats with DIO. However, the expansive distribution pattern of MCH1Rs indicates that $\mathrm{MCH}$ signaling is likely to be involved in a wide range of physiological functions, suggesting that MCH1R antagonists may be useful in human disorders other than obesity. The current scientific literature has shown that MCH1R antagonists are efficacious in animal models of depression, anxiety, sleep, and reward. The neuroanatomical and peripheral distribution of $\mathrm{MCH} 1$ receptors suggest that $\mathrm{MCH}$ is involved in more functions than are currently known. MCH1R antagonists will be invaluable tools for discovering additional functions of $\mathrm{MCH}$ signaling and will likely have therapeutic value in more disorders than are reviewed here.

Acknowledgement This work was supported by grants DA024746, MH60231, and a NARSAD Distinguished Investigator Award to O.C. S.C. is supported by the Davis Foundation Postdoctoral Fellowship Program in Eating Disorders Research supported by Hilda and Preston Davis Foundation. C.L was supported by wonkwang universtiy research fund 2010 .

Open Access This article is distributed under the terms of the Creative Commons Attribution Noncommercial License which permits any noncommercial use, distribution, and reproduction in any medium, provided the original author(s) and source are credited.

\section{References}

Able SL, Ivarsson M, Fish RL, Clarke TL, McCourt C, Duckworth JM, Napier C, Katugampola SD (2009) Localisation of melaninconcentrating hormone receptor 1 in rat brain and evidence that sleep parameters are not altered despite high central receptor occupancy. Eur J Pharmacol 616:101-106

Adamantidis A, Salvert D, Goutagny R, Lakaye B, Gervasoni D, Grisar T, Luppi PH, Fort P (2008) Sleep architecture of the melanin-concentrating hormone receptor 1-knockout mice. Eur J Neurosci 27:1793-1800

Ahnaou A, Drinkenburg WH, Bouwknecht JA, Alcazar J, Steckler T, Dautzenberg FM (2008) Blocking melanin-concentrating hormone MCH1 receptor affects rat sleep-wake architecture. Eur J Pharmacol 579:177-188

Audinot V, Zuana OD, Fabry N, Ouvry C, Nosjean O, Henlin JM, Fauchere JL, Boutin JA (2009) S38151 [p-guanidinobenzoyl[Des-Gly(10)]-MCH(7-17)] is a potent and selective antagonist at the $\mathrm{MCH}(1)$ receptor and has anti-feeding properties in vivo. Peptides 30:1997-2007
Bachner D, Kreienkamp H, Weise C, Buck F, Richter D (1999) Identification of melanin concentrating hormone $(\mathrm{MCH})$ as the natural ligand for the orphan somatostatin-like receptor 1 (SLC-1). FEBS Lett 457:522-524

Borowsky B, Durkin MM, Ogozalek K, Marzabadi MR, DeLeon J, Lagu B, Heurich R, Lichtblau H, Shaposhnik Z, Daniewska I, Blackburn TP, Branchek TA, Gerald C, Vaysse PJ, Forray C (2002) Antidepressant, anxiolytic and anorectic effects of a melanin-concentrating hormone-1 receptor antagonist. Nat Med $8: 825-830$

Bradley RL, Kokkotou EG, Maratos-Flier E, Cheatham B (2000) Melanin-concentrating hormone regulates leptin synthesis and secretion in rat adipocytes. Diabetes 49:1073-1077

Chaki S, Funakoshi T, Hirota-Okuno S, Nishiguchi M, Shimazaki T, Iijima M, Grottick AJ, Kanuma K, Omodera K, Sekiguchi Y, Okuyama S, Tran TA, Semple G, Thomsen W (2005) Anxiolytic- and antidepressant-like profile of ATC0065 and ATC0175: nonpeptidic and orally active melanin-concentrating hormone receptor 1 antagonists. J Pharmacol Exp Ther 313:831-839

Chambers J, Ames RS, Bergsma D, Muir A, Fitzgerald LR, Hervieu G, Dytko GM, Foley JJ, Martin J, Liu WS, Park J, Ellis C, Ganguly S, Konchar S, Cluderay J, Leslie R, Wilson S, Sarau HM (1999) Melanin-concentrating hormone is the cognate ligand for the orphan G-protein-coupled receptor SLC-1. Nature 400:261-265

Chung S, Hopf FW, Nagasaki H, Li CY, Belluzzi JD, Bonci A, Civelli O (2009) The melanin-concentrating hormone system modulates cocaine reward. Proc Natl Acad Sci U S A 106:6772-6777

David DJ, Klemenhagen KC, Holick KA, Saxe MD, Mendez I, Santarelli L, Craig DA, Zhong H, Swanson CJ, Hegde LG, Ping XI, Dong D, Marzabadi MR, Gerald CP, Hen R (2007) Efficacy of the MCHR1 antagonist $N$-[3-(1-\{[4-(3, 4-difluorophenoxy) phenyl]methyl $\}$ (4-piperidyl))-4-methylphen yl]-2-methylpropanamide (SNAP 94847) in mouse models of anxiety and depression following acute and chronic administration is independent of hippocampal neurogenesis. J Pharmacol Exp Ther 321:237-248

Detke MJ, Rickels M, Lucki I (1995) Active behaviors in the rat forced swimming test differentially produced by serotonergic and noradrenergic antidepressants. Psychopharmacology (Berl) 121:66-72

Eric Hu X, Wos JA, Dowty ME, Suchanek PM, Ji W, Chambers JB, Benoit SC, Clegg DJ, Reizes O (2008) Small-molecule melaninconcentrating hormone-1 receptor antagonists require brain penetration for inhibition of food intake and reduction in body weight. J Pharmacol Exp Ther 324:206-213

Erondu N, Gantz I, Musser B, Suryawanshi S, Mallick M, Addy C, Cote J, Bray G, Fujioka K, Bays H, Hollander P, Sanabria-Bohorquez SM, Eng W, Langstrom B, Hargreaves RJ, Burns HD, Kanatani A, Fukami T, MacNeil DJ, Gottesdiener KM, Amatruda JM, Kaufman KD, Heymsfield SB (2006) Neuropeptide Y5 receptor antagonism does not induce clinically meaningful weight loss in overweight and obese adults. Cell Metab 4:275-282

Gehlert DR, Rasmussen K, Shaw J, Li X, Ardayfio P, Craft L, Coskun T, Zhang HY, Chen Y, Witkin JM (2009) Preclinical evaluation of melanin-concentrating hormone receptor 1 antagonism for the treatment of obesity and depression. J Pharmacol Exp Ther 329:429-438

Hassani OK, Lee MG, Jones BE (2009) Melanin-concentrating hormone neurons discharge in a reciprocal manner to orexin neurons across the sleep-wake cycle. Proc Natl Acad Sci U S A 106:2418-2422

Hawes BE, Kil E, Green B, O'Neill K, Fried S, Graziano MP (2000) The melanin-concentrating hormone receptor couples to multiple 
$\mathrm{G}$ proteins to activate diverse intracellular signaling pathways. Endocrinology 141:4524-4532

Herman JP, Prewitt CM, Cullinan WE (1996) Neuronal circuit regulation of the hypothalamo-pituitary-adrenocortical stress axis. Crit Rev Neurobiol 10:371-394

Hill J, Duckworth M, Murdock P, Rennie G, Sabido-David C, Ames RS, Szekeres P, Wilson S, Bergsma DJ, Gloger IS, Levy DS, Chambers JK, Muir AI (2001) Molecular cloning and functional characterization of $\mathrm{MCH} 2$, a novel human $\mathrm{MCH}$ receptor. J Biol Chem 276:20125-20129

Huang CQ, Baker T, Schwarz D, Fan J, Heise CE, Zhang M, Goodfellow VS, Markison S, Gogas KR, Chen T, Wang XC, Zhu YF (2005) 1-(4-Amino-phenyl)-pyrrolidin-3-yl-amine and 6-(3amino-pyrrolidin-1-yl)-pyridin-3-yl-amine derivatives as melanin-concentrating hormone receptor-1 antagonists. Bioorg Med Chem Lett 15:3701-3706

Ishihara A, Kanatani A, Mashiko S, Tanaka T, Hidaka M, Gomori A, Iwaasa $\mathrm{H}$, Murai N, Egashira S, Murai T, Mitobe Y, Matsushita H, Okamoto O, Sato N, Jitsuoka M, Fukuroda T, Ohe T, Guan X, MacNeil DJ, Van der Ploeg LH, Nishikibe M, Ishii Y, Ihara M, Fukami T (2006) A neuropeptide Y Y5 antagonist selectively ameliorates body weight gain and associated parameters in dietinduced obese mice. Proc Natl Acad Sci U S A 103:7154-7158

Ito $\mathrm{M}$, Ishihara $\mathrm{A}$, Gomori $\mathrm{A}$, Matsushita $\mathrm{H}$, Ito $\mathrm{M}$, Metzger JM, Marsh DJ, Haga Y, Iwaasa H, Tokita S, Takenaga N, Sato N, Macneil DJ, Moriya M, Kanatani A (2010) Mechanism of the anti-obesity effects induced by a novel melanin-concentrating hormone 1-receptor antagonist in mice. Br J Pharmacol 159:374 383

Kawauchi H, Kawazoe I, Tsubokawa M, Kishida M, Baker BI (1983) Characterization of melanin-concentrating hormone in chum salmon pituitaries. Nature 305:321-323

Kowalski TJ, Spar BD, Weig B, Farley C, Cook J, Ghibaudi L, Fried S, O'Neill K, Del Vecchio RA, McBriar M, Guzik H, Clader J, Hawes BE, Hwa J (2006) Effects of a selective melaninconcentrating hormone 1 receptor antagonist on food intake and energy homeostasis in diet-induced obese mice. Eur J Pharmacol 535:182-191

Lagos P, Torterolo P, Jantos H, Chase MH, Monti JM (2009) Effects on sleep of melanin-concentrating hormone (MCH) microinjections into the dorsal raphe nucleus. Brain Res 1265:103110

Lembo PM, Grazzini E, Cao J, Hubatsch DA, Pelletier M, Hoffert C, St-Onge S, Pou C, Labrecque J, Groblewski T, O'Donnell D, Payza K, Ahmad S, Walker P (1999) The receptor for the orexigenic peptide melanin-concentrating hormone is a Gprotein-coupled receptor. Nat Cell Biol 1:267-271

Luthin DR (2007) Anti-obesity effects of small molecule melaninconcentrating hormone receptor 1 (MCHR1) antagonists. Life Sci $81: 423-440$

Marsh DJ, Hollopeter G, Kafer KE, Palmiter RD (1998) Role of the Y5 neuropeptide Y receptor in feeding and obesity. Nat Med 4:718-721

Marsh DJ, Weingarth DT, Novi DE, Chen HY, Trumbauer ME, Chen AS, Guan XM, Jiang MM, Feng Y, Camacho RE, Shen Z, Frazier EG, Yu H, Metzger JM, Kuca SJ, Shearman LP, Gopal-Truter S, MacNeil DJ, Strack AM, MacIntyre DE, Van der Ploeg LH, Qian S (2002) Melanin-concentrating hormone 1 receptor-deficient mice are lean, hyperactive, and hyperphagic and have altered metabolism. Proc Natl Acad Sci U S A 99:3240-3245

Mashiko S, Ishihara A, Gomori A, Moriya R, Ito M, Iwaasa H, Matsuda M, Feng Y, Shen Z, Marsh DJ, Bednarek MA, MacNeil DJ, Kanatani A (2005) Antiobesity effect of a melaninconcentrating hormone 1 receptor antagonist in diet-induced obese mice. Endocrinology 146:3080-3086
McBriar MD (2006) Recent advances in the discovery of melaninconcentrating hormone receptor antagonists. Curr Opin Drug Discov Devel 9:496-508

Millan MJ, Gobert A, Panayi F, Rivet JM, Dekeyne A, Brocco M, Ortuno JC, Di Cara B (2008) The melanin-concentrating hormone1 receptor antagonists, SNAP-7941 and GW3430, enhance social recognition and dialysate levels of acetylcholine in the frontal cortex of rats. Int $\mathrm{J}$ Neuropsychopharmacol 8:1105-1122

Monzon ME, De Barioglio SR (1999) Response to novelty after i.c.v. injection of melanin-concentrating hormone $(\mathrm{MCH})$ in rats. Physiol Behav 67:813-817

Monzon ME, Varas MM, De Barioglio SR (2001) Anxiogenesis induced by nitric oxide synthase inhibition and anxiolytic effect of melanin-concentrating hormone $(\mathrm{MCH})$ in rat brain. Peptides 22:1043-1047

Morens C, Norregaard P, Receveur JM, van Dijk G, Scheurink AJ (2005) Effects of $\mathrm{MCH}$ and a MCH1-receptor antagonist on (palatable) food and water intake. Brain Res 1062:32-38

Nagasaki H, Chung S, Dooley CT, Wang Z, Li C, Saito Y, Clark SD, Houghten RA, Civelli O (2009) The pharmacological properties of a novel MCH1 receptor antagonist isolated from combinatorial libraries. Eur J Pharmacol 602:194-202

Nair SG, Adams-Deutsch T, Pickens CL, Smith DG, Shaham Y (2009) Effects of the MCH1 receptor antagonist SNAP 94847 on high-fat food-reinforced operant responding and reinstatement of food seeking in rats. Psychopharmacology (Berl) 205:129-140

Qu D, Ludwig DS, Gammeltoft S, Piper M, Pelleymounter MA, Cullen MJ, Mathes WF, Przypek R, Kanarek R, Maratos-Flier E (1996) A role for melanin-concentrating hormone in the central regulation of feeding behaviour. Nature 380:243-247

Roy M, David N, Cueva M, Giorgetti M (2007) A study of the involvement of melanin-concentrating hormone receptor 1 (MCHR1) in murine models of depression. Biol Psych 61:174 180

Sailer AW, Sano H, Zeng Z, McDonald TP, Pan J, Pong SS, Feighner SD, Tan CP, Fukami T, Iwaasa H, Hreniuk DL, Morin NR, Sadowski SJ, Ito M, Bansal A, Ky B, Figueroa DJ, Jiang Q, Austin CP, MacNeil DJ, Ishihara A, Ihara M, Kanatani A, Van der Ploeg LH, Howard AD, Liu Q (2001) Identification and characterization of a second melanin-concentrating hormone receptor, MCH-2R. Proc Natl Acad Sci U S A 98:7564-7569

Saito Y, Nothacker HP, Wang Z, Lin SH, Leslie F, Civelli O (1999) Molecular characterization of the melanin-concentratinghormone receptor. Nature 400:265-269

Saito Y, Cheng M, Leslie FM, Civelli O (2001) Expression of the melanin-concentrating hormone $(\mathrm{MCH})$ receptor mRNA in the rat brain. J Comp Neurol 435:26-40

Santarelli L, Saxe M, Gross C, Surget A, Battaglia F, Dulawa S, Weisstaub N, Lee J, Duman R, Arancio O, Belzung C, Hen R (2003) Requirement of hippocampal neurogenesis for the behavioral effects of antidepressants. Science 301:805-809

Shimada M, Tritos NA, Lowell BB, Flier JS, Maratos-Flier E (1998) Mice lacking melanin-concentrating hormone are hypophagic and lean. Nature 396:670-674

Shimomura Y, Mori M, Sugo T, Ishibashi Y, Abe M, Kurokawa T, Onda H, Nishimura O, Sumino Y, Fujino M (1999) Isolation and identification of melanin-concentrating hormone as the endogenous ligand of the SLC-1 receptor. Biochem Biophys Res Commun 261:622-626

Smith DG, Davis RJ, Rorick-Kehn L, Morin M, Witkin JM, McKinzie DL, Nomikos GG, Gehlert DR (2006) Melanin-concentrating hormone-1 receptor modulates neuroendocrine, behavioral, and corticolimbic neurochemical stress responses in mice. Neuropsychopharmacology 31:1135-1145

Smith DG, Hegde LG, Wolinsky TD, Miller S, Papp M, Ping X, Edwards T, Gerald CP, Craig DA (2009) The effects of stressful stimuli and 
hypothalamic-pituitary-adrenal axis activation are reversed by the melanin-concentrating hormone 1 receptor antagonist SNAP 94847 in rodents. Behav Brain Res 197:284-291

Tadayyon M, Welters HJ, Haynes AC, Cluderay JE, Hervieu G (2000) Expression of melanin-concentrating hormone receptors in insulin-producing cells: $\mathrm{MCH}$ stimulates insulin release in RINm5F and CRI-G1 cell-lines. Biochem Biophys Res Commun 275:709-712

Takekawa S, Asami A, Ishihara Y, Terauchi J, Kato K, Shimomura Y, Mori M, Murakoshi H, Kato K, Suzuki N, Nishimura O, Fujino M (2002)
T-226296: a novel, orally active and selective melanin-concentrating hormone receptor antagonist. Eur J Pharmacol 438:129-135

Verret L, Goutagny R, Fort P, Cagnon L, Salvert D, Leger L, Boissard R, Salin P, Peyron C, Luppi P-H (2003) A role of melaninconcentrating hormone producing neurons in the central regulation of paradoxical sleep. BMC Neuroscience 4:19

Willie JT, Sinton CM, Maratos-Flier E, Yanagisawa M (2008) Abnormal response of melanin-concentrating hormone deficient mice to fasting: hyperactivity and rapid eye movement sleep suppression. Neuroscience 156:819-829 